\title{
Microalbuminuria in non-insulin dependent diabetes mellitus: an In- donesian experience
}

I Gde Raka Widiana ${ }^{*}$, Rully Roesli* ${ }^{*}$, Ketut Suwitra ${ }^{\dagger}$

\begin{abstract}
Abstrak
Pada DMTI (diabetes melitus tergantung insulin) dan DMTTI (diabetes melitus tak tergantung insulin), mikroalbuminuria dapat meramalkan komplikasi ginjal dan mortalitas tinggi. Deteksi awal dan terapi dini dari berbagai faktor penyerta mungkin dapat menurunkan albuminuria dan mungkin dapat menghambat progresivitas penyakit menuju gagal ginjal kronik. Berbagai penelitian mengenai mikroalbuminuria pada penderita DMTTI serta faktor-faktor yang terkait telah dilakukan di Indonesia. Mikroalbuminuria dijumpai pada lebih dari sepertiga (39\%) penderita DMTTI dan seperempat (24.7\%) penderita GTG (gangguan toleransi glukosa) di masyarakat dan antara 26 sampai 57\% penderita DMTTI di rumah sakit. Umumnya, penderita DMTTI dengan mikroalbuminuria tidak gemuk. Pada penderita DMTTI dengan mikroalbuminuria, tekanan darah dijumpai lebih tinggi dan retinopati dijumpai lebih sering dibandingkan penderita tanpa mikroalbuminuria. Namun, beberapa fraksi lipid pada profil lipid dijumpai lebih buruk pada penderita DMTTI dengan mikroalbuminuria daripada penderita dengan normoalbuminuria. Beberapa enzim tubulus ginjal, yakni $N A G(N$ - asetil-glukosaminidase) dan IAP ("intestinal alkaline phosphatase") konsentrasinya dijumpai lebih tinggi pada penderita DMTTI dengan mikroalbuminuria daripada penderita tanpa mikroalbuminuria. Enzim-enzim ini mungkin dapat dipakai sebagai petanda gangguan fungsi tubulus pada DMTTI. Pada dua studi perlakuan, captopril dilaporkan bermanfaat menurunkan albuminuria dan meningkatkan $H D L$-kolesterol pada penderita nefropati diabetika yang sebagian besar mengalami mikroalbuminuria (stadium insipien).
\end{abstract}

\begin{abstract}
In both IDDM and NIDDM, microalbuminuria predicts diabetic kidney disease and increased mortality. Early detection and treatment of associated factors may reduce albuminuria and retard the progression toward chronic renal failure. With regard to microalbuminuria in NIDDM patients and its associated factors, studies have been done in Indonesia. Microalbuminuria was found in more than one third (39\%) of NIDDM patients and in one quarter (24.7\%) of IGT patients in the community, and in 26 to $57 \%$ of NIDDM patients in the hospital setting. Generally, NIDDM patients with microalbuminuria were non-obese. There was a higher blood pressure and more retinopathy in microalbuminuric NIDDM patients than in normoalbuminuric ones. However, the lipid profile was inconsistently worse in microalbuminuric than normoalbuminuric NIDDM patients. Tubular enzymes namely NAG ( $N$-acetyl- $\beta$-glucosaminidase) and IAP (intestinal alkaline phosphatase) were found higher in NIDDM patients with microalbuminuria than those without microalbuminuria. These enzymes were proposed as markers of early tubular changes in NIDDM. In two interventional studies, captopril was beneficial in reducing albuminuria and increasing HDL-cholesterol in nephropathy patients who mostly were in the incipient (microalbuminuric) stage of diabetic nephropathy.
\end{abstract}

Keywords : non-insulin dependent diabetes mellitus, microalbuminuria, Indonesia

Diabetic nephropathy is a leading cause of renal failure in developed and developing countries. It develops in approximately one-third of patients with type 1 (insulin-dependent) and in similar number of patients with type 2 (non-insulin dependent) diabetes and

\footnotetext{
* Department of Medicine Wangaya General Hospital, Bali, Indonesia

** Subdepartment of Nephrology \& Hypertension Department of Medicine, Padjadjaran University, Bandung, Indonesia

+ Subdepartment of Nephrology \& Hypertension Department of Medicine, Udayana University, Bali, Indonesia
}

progressing in the majority to end-stage disease requiring dialysis or transplantation. ${ }^{1}$ Diabetic nephropathy characterized by increased proteinuria, raised blood pressure, and glomerular changes, carries 20 to 40 fold increased risk of early mortality. ${ }^{2}$ In IDDM (insulindependent diabetes mellitus) nephropathy with endstage renal disease usually takes about 25-30 years to develop. However, in NIDDM (non-insulin- dependent diabetes mellitus) the natural history of renal diseases is not well defined. ${ }^{3}$

Mogensen classified the natural history of renal involvement in IDDM in five stages. ${ }^{4,5}$ At diagnosis, there 
are acute reversible changes (stage I). Stage II, usually lasts ten years, is characterized by normal hyperfunction and hypertrophy of glomeruli, without clinical or laboratory signs. In stage III, taking place during the second decade, a very characteristic abnormality develops, namely microalbuminuria. The third decade (stage IV) is characterized by well-known clinical apparent diabetic nephropathy, with macroproteinuria, increasing blood pressure, and linear fall in GFR, leading to end-stage renal failure, namely stage $\mathrm{V} .{ }^{4}$ The course of diabetic nephropathy in NIDDM is not yet well defined. The onset of disease in NIDDM is usually not clearly defined and the metabolic disarrangement may not be as pronounced as it is in IDDM. The same classification may be used in NIDDM but the situation is much more complicated and somewhat different, because hyperfiltration is less pronounced and maybe absent. ${ }^{5}$ In IDDM, microalbuminuria, defined as urinary albumin excretion rate ranging 20-200 $\mu \mathrm{g}$ per minute showed as strong predictive value for subsequent renal disease. ${ }^{6-8}$ In the early stage, microalbuminuria is a specific clinical marker that can predict clinical nephropathy in the future course of the disease. The stage of overt clinical diabetic nephropathy which characterized persistent proteinuria and reduced renal function as the main symptoms, is considered to be irreversible and will slowly progresses to end-stage renal disease. Microalbuminuria can also predict the increase of mortality in NIDDM patients. After 9 years of follow up, Mogensen (1987) reported that microalbuminuric NIDDM patients have a mortality of $148 \%$ higher than diabetic controls. ${ }^{9}$ In NIDDM, microalbuminuria is found in $25 \%$ of patients. It is also found quite common at diagnosis of NIDDM. ${ }^{10}$ In these patients, there may be a number of factors beside renal disease which contribute to the increase in urinary albumin excretion rate. The confounder including essential renal disease and cardiac decompensation is suspected. NIDDM patients have a significant increase of blood pressure. Abnormal lipid profiles are also found in some but not all microalbuminuric diabetes. ${ }^{5}$

In Indonesia, prevalence of diabetes ranges between $1-3 \%$, the number can be larger in big cities and there is a trend of increase in its prevalence. All types of diabetes can be found, however, as in other countries, the most frequent type found is NIDDM. The percentage of IDDM is very small and there were only few reports of MRDM particularly from Bandung, Semarang, Yogyakarta, and Surabaya (Symposium on The Paradigm of Diabetic Nephropathy and Nephrocardiologic Complications in NIDDM, Bandung 1996; The IXth KOPAPDI, Denpasar 1993).
Reports in Indonesia showed that diabetic nephropathy was the second highest cause of end-stage renal disease who underwent maintenance dialysis. It was reported $17.6 \%$ in Jakarta (Symposium on Management Aspects of Kidney Diseases, Jakarta 1990), and 22.5\% in Yogyakarta (Darmaatmaja J, Unpublished Review and Study Reports). The Indonesian Society of Nephrology in its annual report, has reported that during 3 years (1993 to 1995) 16-18\% of end-stage renal failure patients with maintenance hemodialysis were associated with diabetes (Indonesian Society of Nephrology. Annual report 1996, unpublished).

High cost of replacement therapy with dialysis or kidney transplantation are the only choice to maintain life in these patients. Therefore, possible preventive measures in preventing or retarding the development to end-stage renal failure is very important.

Early detection may be possible by detecting microalbuminuria as a routine test for NIDDM patients, at a particular situation. Associated factors that may aggravate the development to clinical nephropathy may also be detected and treated promptly. This paper attempts to elucidate studies in Indonesia regarding microalbuminuria and associated factors in diabetes mellitus particularly in NIDDM patients that may be beneficial to the possible preventive measures.

\section{EXPLORATIVE STUDIES}

Community-based epidemiologic studies to explore microalbuminuria in diabetes is rare in Indonesia. Most of the studies were hospital-based with different study methods and subject selection. In Ujung Pandang, Adam \& Sampeling found that out of 50 NIDDM patients examined, $44 \%$ had microalbuminuria, $28 \%$ had normoalbuminuria, and $28 \%$ with macroalbuminuria (National Congress of the Indonesian Society of Internal Medicine, Yogyakarta 1990). In Surabaya, Soewanto and Tjokroprawiro reported that among 46 NIDDM patients screened, $26.8 \%$ had microalbuminuria (National Symposium on Endocrinology and Metabolism, Surabaya 1997). In Yogyakarta, Widiana et al. screened 24-hours urinary samples for microalbuminuria in NIDDM patients. Using qualitative immunoturbidimetry method, among 104 patients examined, 57\% had microalbuminuria, $33 \%$ normoalbuminuria, and $10 \%$ had macroalbuminuria (3rd National Congress of Indonesian Society of Endocrinology, Semarang 1993). 
Soesilawati et al. in Jakarta using semiquantitative Micral test ${ }^{\circledR}$, found $31.6 \%$ of NIDDM patients had microalbuminuria (3rd National Congress of Indonesian Society of Endocrinology, Semarang 1993).

A community based-study was done in Singaparna, west Java Province. The population of this sub-district of Tasikmalaya Regency was 113,401 . The study was carried out in subjects aged of more than 20 years. Using the selection criteria, 28,571 patients were screened by Accutrend test ${ }^{\circledR}$ for its blood sugar. The OGTT (oral glucose tolerance test) was used for confirmation of the diagnosis of DM or IGT (impaired glucose tolerance). It was found that crude prevalence of NIDDM was $233(1.03 \%)$ and crude prevalence of IGT was 5009 (18.1\%). Persistent microalbuminuria was diagnosed when at least two out three semiquantitative Micral test conducted within 6 months, were positive. The results of the study showed that prevalence rate of persistent microalbuminuria among NIDDM patients was $39 \%$ and among IGT patients was $24.7 \% .{ }^{11}$

\section{OBSERVATIONAL STUDIES}

In NIDDM, subjects with microalbuminuria were older than those without microalbuminuria. This may also be related to the longer duration of the disease in NIDDM with microalbuminuria subjects compared to those without. Other variables were also analyzed. There was no significant difference found in BMI, blood sugar levels, blood pressure, lipid profile in both groups (see table 1). Although statistically it was not significantly different, subjects with microalbuminuria tend to have a higher both systolic and diastolic blood pressure. Nevertheless, higher ureum and creatinine levels were found in NIDDM subjects. ${ }^{11}$ In this study, urinary enzymes were also examined, consisting of NAG (N- acetyl- $\beta$-D-glucosaminidase), IAP (intestinal alkaline phosphatase), and TNAP (tissue nonspecific alkaline phosphatase). Elevation of these enzymes may reflect early tubular changes. It was found that concentration of the IAP and NAG but not the TNAP enzymes were increased in NIDDM patients with persistent microalbuminuria compared to those without microalbuminuria. It was also shown that NIDDM patients with microalbuminuria had higher frequency of high IAP ( $>2 \mathrm{U} / \mathrm{gr}$ ) and high NAG (>5 $\mathrm{U} / \mathrm{gr}$ ) levels than those without microalbuminuria, that is $44.4 \%$ vs $33.8 \%$ for IAP level and $74.1 \%$ vs $68.1 \%$ for NAB level, consecutively. ${ }^{11}$
Table 1. Characteristics of NIDDM patients with and without persistent microalbuminuria (adapted from Roesli, 1996) ${ }^{11}$

\begin{tabular}{llll}
\hline Characteristics & $\begin{array}{c}\text { NIDDM } \\
\text { without PM\# } \\
\mathrm{n}=83 \\
\text { Mean (SD) }\end{array}$ & $\begin{array}{c}\text { NIDDM } \\
\text { with PM } \\
\mathrm{n}=53 \\
\text { Mean (SD) }\end{array}$ & $\begin{array}{c}\text { p value } \\
\text { (F test) }\end{array}$ \\
\hline 1. Age & $53.2(12.8)$ & $57.8(11.6)$ & 0.066 \\
2. Duration of DM & $27.8(12.7)$ & $41.6(33.8)$ & 0.099 \\
(months) & & & \\
3. BMI (kg/m2) & $22.5(4.3)$ & $23.2(4.3)$ & 0.537 \\
4. Fasting BS (mg/dl) & $159(72)^{*}$ & $181(87)$ & 0.0001 \\
5. 2h-pp BS (mg/dl) & $284(71)^{*}$ & $304(91)$ & 0.0001 \\
6. Systolic BP (mmHg) & $128(21)$ & $137(25)$ & 0.139 \\
7. Diastolic BP (mmHg) & $80(11)$ & $84(12)$ & 0.141 \\
8. Lipids (mg/dl): & & & \\
Total cholesterol & $250(91)$ & $242(47)$ & 0.070 \\
HDL-cholesterol & $47(15)$ & $47(13)$ & 0.187 \\
LDL-cholesterol & $160(88)$ & $155(38)$ & 0.477 \\
LDL-cholesterol & $207(133)$ & $216(130)$ & 0.272 \\
Triglyceride & $0.83(0.26)^{*}$ & $0.97(0.37)$ & 0.0013 \\
9. Creatinine (mg/dl) & $0.83(0.26)^{*}$ & $0.97(0.37)$ & 0.0013 \\
10. Ureum (mg/dl) & $24.1(8.6)^{*}$ & $30.1(13.2)$ & 0.0001 \\
\hline & & & \\
\hline
\end{tabular}

\# persistent microalbuminuria, * significant

High blood pressure is considered as a major aggravating and cardiovascular risk factor. In a study done in Yogyakarta, Widiana has reported that NIDDM patients with persistent microalbuminuria diagnosed as incipient diabetic nephropathy had significant higher blood pressure than NIDDM patients with normoalbuminuria. This study recruited 34 patients with incipient diabetic nephropathy and 34 controls (NIDDM patients with normoalbuminuria), matched for age and sex. Patients with incipient diabetic nephropathy tend to have longer diabetes (mean 5.9 years vs 4.2 years) and had more frequent retinopathy $(50.0 \%$ vs $17.6 \%)$. Most of the retinopathy in both groups was of the background type. However, since age of both groups was similar means that microalbuminuria may be related to the longer onset of NIDDM (see table 2). Blood pressure were found higher both in systolic $(143 \pm 1 \mathrm{mmHg}$ vs $127 \pm 17$ $\mathrm{mmHg}, \mathrm{p}<0.05)$ and in diastolic $(89 \pm 9$ vs $81 \pm 11$ $\mathrm{mmHg}, \mathrm{p}<0.05)$ in patients with incipient diabetic nephropathy than those without diabetic nephropathy. Diastolic blood pressure of $95 \mathrm{mmHg}$ or more was found more frequent in incipient diabetic nephropathy patients than those without diabetic nephropathy (32\% vs $15 \%, \mathrm{p}<0.05)$. Poor correlation was found between urinary albumin excretion rate and diastolic blood pressure in incipient diabetic nephropathy patients $(r=0.14)$ and controls $(r=0.07) .^{12}$ 
Table 2. Clinical characteristics of NIDDM patients with and without IDN* (adapted from Widiana et al., 1993)

\begin{tabular}{lccc}
\hline Characteristics & $\begin{array}{c}\text { NIDDM } \\
\text { with IDN } \\
n=34 \\
\text { Mean (SD) }\end{array}$ & $\begin{array}{c}\text { NIDDM } \\
\text { without IDN } \\
\mathrm{n}=34 \\
\text { Mean (SD) }\end{array}$ & p value \\
\hline I. M/F & $17 / 17$ & $17 / 17$ & \\
2. Age (years) & $47.91(13.03)$ & $47.41(13.67)$ & 0.438 \\
3. Duration of DM (years) & $5.92(4.64)$ & $4.16(3.68)$ & 0.062 \\
4. RBW** (\%) & $86.32(17.06)$ & $86.76(22.59)$ & 0.464 \\
5. Retinopathy & $17(50.0 \%)$ & $6(17.6 \%)$ & 0.010 \\
Background type & 14 & 5 & \\
Proliferative type & 3 & 1 & 0.330 \\
6. Neuropathy & 18 & 13 & \\
\hline
\end{tabular}

* Incipient diabetic nephropathy, ${ }^{* *}$ Relative body weight

To determine the relationship between blood pressure and some aggravating factors namely dyslipidemias, diabetic retinopathy, and microalbuminuria in NIDDM patients, Widiana, in Yogyakarta has screened 106 NIDDM for blood pressure, lipid profile, and the presence of retinopathy and microalbuminuria. ${ }^{13}$ Out of those patients; $44(41.5 \%)$ had dyslipidemia, 36 (34.2\%) had diabetic retinopathy, and $59(55.6 \%)$ had microalbuminuria. It was found, that NIDDM patients with one or more of the three (dyslipidemia, retinopathy, and microalbuminuria) aggravating factors had higher blood pressure than those without any aggravating factor. Meanwhile, patients without any aggravating factor had mean blood pressure around $120 / 80 \mathrm{mmHg}$ (see table 3). Most of patients with aggravating factors had a mean blood pressure of more than $140 / 85 \mathrm{mmHg}$, levels of which is considered to increase cardiovascular morbidity and mortality in diabetes and should be treated. Fifty percent or more patients with one or more above mentioned aggravating factors had a blood pressure of $140 / 90 \mathrm{mmHg}$ or more. Meanwhile, around 30\% of NIDDM patients without any aggravating factor had a blood pressure of $140 / 90$ or more (see table 4).

In another study involving 68 NIDDM patients, other aspect of cardiovascular risk factor, namely dyslipidemia was evaluated. ${ }^{14}$ It was reported that the total cholesterol level in NIDDM patients with microalbuminuria was higher than that found in NDDM patients without microalbuminuria (see table 5). In contrast, the HDL-cholesterol level in NIDDM patients with microalbuminuria was lower than that in NIDDM patients without microalbuminuria. Beside of high total cholesterol and low HDL- cholesterol levels, NIDDM patients with microalbuminuria had also an abnormal fraction of lipids including ratio of total cholesterol/HDL-cholesterol which is more than 4,5 . Triglyceride and LDL-cholesterol levels were similar between two groups. It was also found that retinopathy was more frequent among NIDDM patients with microalbuminuria than those without.

Table 3. Blood pressure in 106 NIDDM patients without any aggravating factor and with one or more aggravating factors (adapted from Widiana, 1996) ${ }^{13}$

\begin{tabular}{|c|c|c|c|c|}
\hline \multirow{3}{*}{ Groups } & \multicolumn{4}{|c|}{ Blood pressure } \\
\hline & \multicolumn{2}{|c|}{$\begin{array}{l}\text { Systolic } \\
(\mathrm{mmHg})\end{array}$} & \multicolumn{2}{|c|}{$\begin{array}{r}\text { Diastolic } \\
(\mathrm{mmHg})\end{array}$} \\
\hline & Mean & SD & Mean & SD \\
\hline 1. NIDDM without aggravating factor & 123 & 19 & 79 & 10 \\
\hline 2. NIDDM with dysl.* & 139 & 22 & 83 & 10 \\
\hline 3. NIDDM with ret.** & 147 & 15 & 93 & 4 \\
\hline 4. NIDDM with mic.\# & 134 & 10 & 85 & 8 \\
\hline 5. NIDDM with dysl.\& ret. & 147 & 14 & 86 & 18 \\
\hline 6. NIDDM with ret.\& mic. & 137 & 9 & 83 & 7 \\
\hline 7. NIDDM with dysl.\& mic. & 154 & 15 & 91 & 9 \\
\hline 8. NIDDM with dysl.\& ret \& mic. & 162 & 24 & 93 & 9 \\
\hline
\end{tabular}

* dyslipidemias, ** retinopathy, \# microalbuminuria

Table 4. Frequency distribution of NIDDM patients without any aggravating factor and with one or more aggravating factors with blood pressure $140 / 90 \mathrm{mmHg}$ (adapted from Widiana, 1996) $^{21}$

\begin{tabular}{|c|c|c|c|}
\hline \multirow{2}{*}{ Groups } & & \multicolumn{2}{|c|}{$\begin{array}{l}\text { Blood pressure } \\
\geq 140 / 90 \mathrm{mmHg}\end{array}$} \\
\hline & & $\mathrm{n}$ & $\%$ \\
\hline \multicolumn{2}{|c|}{ 1. NIDDM without aggravating factor $(\mathrm{N}=22)$} & 7 & 31.8 \\
\hline 2. NIDDM with dysl.* & $(\mathrm{N}=6)$ & 4 & 66.7 \\
\hline 3. NIDDM with ret.** & $(\mathrm{N}=4)$ & 4 & 100.0 \\
\hline 4. NIDDM with mic.*** & $(\mathrm{N}=13)$ & 8 & 61.5 \\
\hline 5. NIDDM with dysl.\& ret. & $(\mathrm{N}=4)$ & 2 & 50.0 \\
\hline 6. NIDDM with ret.\& mic. & $(\mathrm{N}=12)$ & 6 & 50.0 \\
\hline 7. NIDDM with dysl.\& mic. & $(\mathrm{N}=18)$ & 17 & 94.4 \\
\hline 8. NIDDM with dysi.\& ret.\& mic. & $(N=16)$ & 15 & 93.8 \\
\hline
\end{tabular}

* dyslipidemia, ** retinopathy, *** microalbuminuria 
Table 5. Lipid profile of NIDDM patients with and without microalbuminuria (adapted from Widiana et al, 1994) ${ }^{22}$

\begin{tabular}{|c|c|c|c|c|c|}
\hline \multirow[t]{2}{*}{ Lipids (mg/dl) } & \multicolumn{2}{|c|}{$\begin{array}{l}\text { NIDDM } \\
\text { with mic.* }\end{array}$} & \multicolumn{2}{|c|}{$\begin{array}{l}\text { NIDDM } \\
\text { without mic. }\end{array}$} & \multirow[t]{2}{*}{$P$ value } \\
\hline & Mean & SD & Mean & SD & \\
\hline 1. Total cholesterol & 200 & 53 & 178 & 53 & 0.06 \\
\hline 2. HDL-cholesterol & 35 & 13 & 43 & 12 & 0.01 \\
\hline 3. LDL-cholesterol & 112 & 59 & 113 & 42 & 0.24 \\
\hline 4. Triglyceride & 173 & 89 & 164 & 69 & 0.31 \\
\hline $\begin{array}{l}\text { 5. Total-cholesterol: } \\
\text { HDL-cholesterol }\end{array}$ & 6.3 & 3.0 & 4.1 & 1.1 & 0.00 \\
\hline
\end{tabular}

* microalbuminuria

\section{INTERVENTIONAL STUDIES}

There were some reports of interventional studies in microalbuminuric diabetics in Indonesia. In Yogyakarta, Sja'bani et al reported a study to evaluate the effect of captopril on urinary albumin excretion in NIDDM with albuminuria. The study showed that after two months, captopril $12,5 \mathrm{mg}$ thrice a day decreases albuminuria without significantly reducing the blood pressure in NIDDM patients. Patients included in the study had diabetic nephropathy. Most (36 out of 40 patients) of the patients were in the stage of incipient diabetic nephropathy. Patients were given captopril 12.5 thrice a day or placebo for two months by random allocation. During the study 42 patients were included, 2 in placebo group dropped-out in the first month. Out of 40 patients analyzed ( 21 males; 19 females) 20 patients received captopril (age 53.60 years) and 20 patients received placebo (age 50.80 years). There were no significant difference of urinary albumin excretion rate (UAER) in both groups at baseline (195.0 vs $346.1 \mathrm{mg}$ per 24 hours, $\mathrm{p}=0.133$ ), and no significant difference of sex, age, duration of diabetes, systolic and diastolic blood pressure, blood sugar, serum creatinine levels, and the presence of retinopathy in both groups. After one month treatment, there was no significant decreased of UAER between the two groups (21.6 vs $10.9 \mathrm{mg} / 24 \mathrm{hr}, \mathrm{p}>0.05$ ). After two months treatment, there was a significant decreased of UAER in captopril group (195.0 to $78.3 \mathrm{mg} / 24 \mathrm{hr}$, p $<0.05$ ) but not in placebo group (346.1 to $290.1 \mathrm{mg} / 24$ $\mathrm{hr}, \mathrm{p}>0.05)$. Although there was around twice reduction (149 to $141 \mathrm{mmHg}$ vs 145 to $141 \mathrm{mmHg}$ ) in systolic BP and around 1.5 times reduction ( 90 to 84 $\mathrm{mmHg}$ vs 87 to $83 \mathrm{mmHg}$ ) in diastolic $\mathrm{BP}$, no significant difference of systolic BP before treatment (149 vs $145 \mathrm{mmHg}, p>0.05)$ and two months after treatment (141 vs $141 \mathrm{mmHg}, \mathrm{p}>0.05$ ) of both groups, and diastolic BP before treatment $(90$ vs $87 \mathrm{mmHg}, \mathrm{p}>$
0.05 ) and two months after treatment ( $84 \mathrm{vs} 83 \mathrm{mmHg}$, $\mathrm{p}>0.05$ ) were found. More interestingly, creatinine levels tend to decrease in captopril group (1.7 to 1.3 $\mathrm{mg} / \mathrm{dl}, \mathrm{p}>0.05$ ) but tend to increase in placebo group $(1.7 \text { to } 1.9 \mathrm{mg} / \mathrm{dl}, \mathrm{p}>0.05 \text { ) (see table } 6)^{15}$

In another study in Yogyakarta, Asdie et al. found that captopril improves lipid profile in NIDDM patients with albuminuria by increasing HDL-cholesterol. In randomized-placebo controlled trial, 40 patients were included in the study and divided in two group to receive captopril $12.5 \mathrm{mg}$ thrice a day or placebo for two months. After two months treatment, there was a significant increased of HDL-cholesterol (39 to 50 $\mathrm{mg} / \mathrm{dl}, \mathrm{p}<0.05)$ in captopril group, but not in placebo group ( 43 to $46 \mathrm{mg} / \mathrm{dl}, \mathrm{p}>0.05$ ). There is some degree of decreased of total- cholesterol/HDL-cholesterol ratio in both captopril and placebo group, 4.8 to 4.0 and 4.6 to 4.2 , or decreased by $16 \%$ and $8 \%$, consecutively. This changes may not related to blood sugar control or body weight, since there was no significant changes of blood sugar levels between baseline and two months after treatment in both groups and similar relative body weight at baseline in both groups were found. However, there was no significant changes of total cholesterol, triglyceride, and LDL- cholesterol levels in both groups (see table 7). ${ }^{16}$

Table 6. Urinary albumin excretion rate (UAER), blood pressure, and creatinine levels in NIDDM patients before and after treatment in captopril and placebo groups (adapted from Sja'bani et al., 1994) ${ }^{15}$

\begin{tabular}{|c|c|c|c|}
\hline Variables & $\begin{array}{l}\text { Captopril group } \\
n=20 \\
\text { Mean (SD) }\end{array}$ & $\begin{array}{c}\text { Placebo group } \\
n=20 \\
\text { Mean (SD) }\end{array}$ & p value \\
\hline \multicolumn{4}{|l|}{ UAER } \\
\hline Before treatment & $195.0(209.3)$ & $346.1(561.2)$ & 0.133 \\
\hline One month & $173.4(191.5)$ & $335.2(401.4)$ & 0.215 \\
\hline difference & $21.6(64.4)^{*}$ & $10.9(154.3)^{* * *}$ & \\
\hline Two months & $78.3(79.7)$ & $290.1(370.0)$ & 0.032 \\
\hline difference & $116.7(50.0)^{* * * *}$ & $55.9(150.3) * * * *$ & \\
\hline \multicolumn{4}{|l|}{ Blood pressure } \\
\hline \multicolumn{4}{|l|}{ Systolic } \\
\hline Before treatment & $149(17)$ & $145(24)$ & 0.277 \\
\hline Two months & $141(19)$ & $141(26)$ & 0.045 \\
\hline \multicolumn{4}{|l|}{ Diastolic } \\
\hline Before treatment & $90(9)$ & $87(9)$ & 0.211 \\
\hline Two months & $84(8)$ & $83(9)$ & 0.428 \\
\hline \multicolumn{4}{|l|}{ Creatinine levels } \\
\hline Before treatment & $1.7(1.7)$ & $1.7(1.4)$ & 0.452 \\
\hline Two months & $1.3(0.9)$ & $1.9(1.7)$ & 0.093 \\
\hline difference & $-0.16(1.4)$ & $0.2(0.9)$ & \\
\hline
\end{tabular}

* $p$ of difference $=0.367,{ }^{* *} p$ of difference $=0,472$,

$* * * \mathrm{p}$ of difference $=0.012, * * * * \mathrm{p}$ of difference $=0.355$ 
Table 7. Lipid profile in NIDDM with persistent albuminuria in captopril and placebo group before and after two months treatment (adapted from Asdie et al., 1994) ${ }^{16}$

\begin{tabular}{|c|c|c|}
\hline Variables & $\begin{array}{c}\text { Captopril group } \\
n=20 \\
\text { Mean (SD) }\end{array}$ & $\begin{array}{c}\text { Placebo group } \\
n=20 \\
\text { Mean (SD) }\end{array}$ \\
\hline
\end{tabular}

Lipids (mg/dl)

Total cholesterol

Baseline

Two months

Difference

(Statistics)

$191(75)$

$206(61)$

$14(49)$

$(\mathrm{p}=0.25)$

$198(65)$

$194(57)$

$-3(41)$

$(p=0.43)$

Triglyceride

Baseline

Two months

$160(80)$

$149(53)$

Difference

(Statistics)

$-10(58)$

$(\mathrm{p}=0.31)$

$170(73)$

$169(76)$

$-0.6(57)$

$(\mathrm{p}=0.49)$

HDL-cholesterol

Baseline

Two months

Difference

(Statistics)

39 (14)

$50(14)$

$10(13)$

$(\mathrm{p}=0.4)$

43 (27)

$46(24)$

2 (12)

$(p=0.23)$

LDL-cholesterol
Baseline
Two months
Difference

$132(49)$

133 (49)

$-1(22)$

$123(66)$

$133(53)$

$-9(61)$

$(p=0.47)$

$(\mathrm{p}=0.30)$

Blood sugar ( $\mathrm{mg} / \mathrm{dl}$ )

Fasting

Baseline

Two months

205 (92)

$153(76)$

$193(79)$

$130(78)$

NS*

2 hours pp

Baseline

$261(85)$

Two months

202 (84)

204 (86) NS

187 (108) NS

Relative body weight (\%)

Baseline

$93(21)$

$91(15)$

LDL-cholesterol

Baseline

Two months

Difference

$132(49)$

133 (49)

$123(66)$

$133(53)$

$-9(61)$

(Statistics)

$(\mathrm{p}=0.47)$

$(\mathrm{p}=0.30)$

Blood sugar (mg/dl)

Fasting

Two months

$193(79)$

$130(78)$

2 hours pp

Baseline

Two months

$261(85)$

202 (84)

204 (86)

187 (108)

NS*

NS

NS

Relative body weight (\%)

Baseline

$93(21)$

91 (15)

NS

\section{DISCUSSION}

Some studies regarding microalbuminuria in NIDDM have been carried out in Indonesia. Most of the studies were hospital- based. Prevalence of microalbuminuria in hospital setting varies 26 to $57 \%$. A communitybased study found a prevalence rate of $39 \%$ in NIDDM patients and $24.7 \%$ in IGT patients. Interestingly, it was revealed in the study by Roesli that the IGT group, which is also known as a prediabetic state of NIDDM, has a high prevalence of persistent microalbuminuria. At least one important question can be raised based on this result. Is microalbuminuria a feature of the prediabetic state in NIDDM? ${ }^{11}$ However, Viberti argued that in prediabetic state, some factors related to microalbuminuria should be taken into account. Studies have shown that essential hypertension, obesity, insulin resistence, and cardiovascular disease are prevalent in subjects known to have $\mathrm{X}$-syndrome. Some studies also found that essential hypertension, obesity, hypertension, coronary heart disease were found with increased frequency in patients with raised albumin excretion (Viberti 1996, oral communication). In the study by Roesli, it was also found that glycaemic control was significantly different among NIDDM subjects with and without microalbuminuria, IGT subjects with and without microalbuminuria, with $\mathrm{p}=0.001$ both for fasting and 2 hours post-load blood sugar levels (data is not revealed). ${ }^{11}$ Blood sugar levels in microalbuminuric were higher than normoalbuminuric subjects both in NIDDM and IGT subjects. It should be elucidated whether the presence of microalbuminuria related to the difference in blood sugar control or the gradation of insulin resistance related to the stage of the disease. Since, many study showed the relationship between microalbuminuria and glycaemic levels, which not only found in diabetic patients, but also found in patient with IGT. ${ }^{17}$

NIDDM patients with microalbuminuria are older and having diabetes longer than those without microalbuminuria, as shown by Widiana et al ${ }^{14}$ and by Roesli. ${ }^{11}$ Those studies showed normal mean relative body weight and body mass index, and also there were no difference in those variables in NIDDM patients with and without microalbuminuria. These results suggest that obesity is not obvious in NIDDM patients with microalbuminuria. ${ }^{11,12}$ Retinopathy is more prevalent in NIDDM patients with microalbuminuria. Widiana et al., reported that retinopathy was almost three times more frequent in NIDDM patients with microalbuminuria than those without microalbuminuria. ${ }^{12}$ Blood pressure is higher both systolic and diastolic in NIDDM patients with microalbuminuria than those

* non-significant 
without. Patients with microalbuminuria who had diastolic blood pressure $95 \mathrm{mmHg}$ or more were more than twice as many than those without microalbuminuria. ${ }^{13}$ In community-based study by Roesli, blood pressure was within normal range and although slightly higher in NIDDM patients with microalbuminuria but no significant difference was found. ${ }^{11}$ It was also generally found that, the more aggravating factors analyzed (dyslipidemia, retinopathy, and microalbuminuria) the higher blood pressure both systolic and diastolic, and also the more frequent those who have hypertension. Most of patients with aggravating factors had mean blood pressure of $140 / 85 \mathrm{mmHg}$ and more than 50\% of them had high blood pressure, i.e. $\geq 140 / 90$ mmHg. ${ }^{13}$

In hospital-based study, there was no significant differences in lipid profile between NIDDM patients with microalbuminuria than those without microalbuminuria. The mean values levels of total cholesterol, LDL-cholesterol, HDL-cholesterol, and triglyceride were about the same in those group. However, it was found that NIDDM patients with microalbuminuria had significant lower HDL-cholesterol and significant higher in total-cholesterol/HDL-cholesterol ratio with mean value of more than 4.5 than those without microalbuminuria. ${ }^{14}$

In a randomized placebo-controlled trial, captopril is beneficial in reducing urinary albumin excretion in NIDDM patients with albuminuria. ${ }^{15}$ The reduction of albumin excretion seemed to be caused by captopril, independent of its blood pressure lowering effect. Although blood pressure was slightly reduced before and after treatment, however, no significant difference was found. Captopril also seem beneficial in improving lipid profile in NIDDM patients with microalbuminuria. It increases HDL-cholesterol levels, without significantly changes blood sugar levels and may therefore blood sugar independent. ${ }^{96}$

Interestingly, a community-based study reported that tubular enzymes levels, namely NAG (N-acetyl- $\beta$-Dglucosaminidase) and IAP (intestinal alkaline phosphatase) were higher in NIDDM patients with microalbuminuria than those without microalbuminuria. The author proposed speculations to explain these findings. First, microalbuminuria was not only due to the increase in glomerular passage of albumin but also due to the decrease in the protein resorbtion capacity of the tubules. The early tubular changes in these patients were identified by the increased urinary IAP and NAG levels. Second, the presence of microalbuminuria and high level of IAP and NAG are coincidental. They were both detected in the urine as markers for early glomerular and tubular changes, respectively. ${ }^{11}$

In summary, twenty six to fifty seven percent of NIDDM patients in hospital settings have microalbuminuria. More than a third of NIDDM patients and one quarter of IGT subjects have microalbuminuria in community-based study. Generally, NIDDM patients with microalbuminuria have higher blood pressure and more retinopathy, inconsistent worse lipid profile, higher NAG- and IAP-level, and are non-obese. Cohort-studies and morphological studies are needed to confirm whether NAG and IAP can be used as markers of early tubular changes in NIDDM. A longerterm randomized clinical trials with more subjects is needed to confirm the beneficial effect of captopril on albuminuria and lipid profile in NIDDM patients.

\section{REFERENCES}

1. Krolewski AS, Warram JH, Chrislieb AR, Busick EJ, Kahn CR. Changing natural history of nephropathy in type 1 diabetes. Am J Med 1985;78:785-94.

2. Borch-Johnsen K, Andersen PK, Deckert T. The effect of proteinuria on relative mortality in type 1 (insulin-dependent diabetes mellitus). Diabetologia 1985;28:590-6.

3. Schmitz A. Nephropathy in non-insulin dependent diabetes mellitus and perspective for intervention. Diab Nutr Metab 1995; 7:135-48

4. Mogensen CE. Prediction of clinical diabetic nephropathy in IDDM patients. Alternatives to microalbuminuria? Diabetes 1990;39:761-77.

5. Mogensen CE. Natural history and potential prevention of diabetic nephropathy in insulin-dependent and non-insulin dependent diabetic patients. In : E1 Nahas AM, Mallick NP, Anderson S, editors. Prevention of progressive renal failure. Oxford: Oxford University Press; 1993; p 259-302.

6. Mogensen CE, Christiensen CK. Predicting diabetic nephropathy in insulin-dependent diabetes mellitus patients. N Engl J Med 1984;311:89-93.

7. Mathiesen ER, Oxenboll B, Johansen K, Svendsen PA, Deckere T. Incipient nephropathy in type 1 insulin-dependent diabetes. Diabetologia 1984;24:204-10.

8. Viberti GC, Jarret RJ, Mahmud U, Hill RD, Argyropoulos A, Keen H. Microalbuminuria as a predictor of clinical nephropathy in insulin-dependent diabetes mellitus. Lancet 1982:1430-2.

9. Mogensen CE. Microalbuminuria as a predictor of clinical diabetic nephropathy. Kidney Int 1987;31:673-89.

10. Gall MA. Prevalence of micro and macroalbuminuria, arterial hypertension, retinopathy and large vessel disease in european type 2 (non-insulin dependent) diabetes patients. Diabetologia 1991;34:655-61.

11. Roesli R. Specific markers of early renal involvement in diabetes in study on the prevalence of non-insulin dependent 
diabetes and impaired glucose tolerance in the rural area of West Java. Highlighting the specific markers on the early renal involvement [dissertation]. Antwerpen (Belgium): Univ. of Antwerpen; 1996.

12. Widiana IGR, Sja'bani M, Asdie AH. Blood pressure in non-insulin dependent diabetes mellitus patients with incipent diabetic nephropathy. Acta Medica Indonesiana 1993;21:52-9 (in Indonesian).

13. Widiana IGR. Blood pressure in NIDDM (non-insulin dependent diabetes mellitus) with some aggravating factors. Medika 1996;11:855-9 (in Indonesian).

14. Widiana IGR, Sja'bani M, Asdie AH. Lipid profile in NIDDM (non- insulin dependent diabetes mellitus) with microalbuminuria. Journal of Medical Sciences 1994;26: 21-7 (in Indonesian).

15. Sja'bani M, Widiana IGR, Asdie AH. Effect of captopril on albuminuria in diabetics. Medika 1994;20:41-8 (in Indonesian).

16. Asdie AH, Widiana IGR, Wiyono P. Effect of captopril on lipid profile in non-insulin dependent diabetes mellitus with albuminuria. Indonesian Clin Epidemio Biostatistics 1994;1:17-22 (in Indonesian).

17. Hotta O, Taguma Y, Mitsuoka M, Takeshita K, Takashita K, Takahashi H. Urinary albumin excretion in patients with non-insulin-dependent diabetes mellitus in early microalbuminuric stage. Nephron 1991;58:23-26. 